Uniwersytet im. Adama Mickiewicza, Poznań

\title{
Kolegialna głowa państwa we współczesnych systemach politycznych
}

\section{Wprowadzenie}

Wa czele każdego państwa stoi osoba bądź osoby, które spełniają wiele 1 określonych funkcji (nie tylko prawnych, ale też i symbolicznych). Konstruując aparat pojęciowy dla niniejszego artykułu dokonano określenia kluczowego dla pracy terminu głowa państwa, posłując się przede wszystkim definicjami R. Herbuta i B. Dziemidok ${ }^{1}$.

Za kolegialną głowę państwa należy uznać dwie lub więcej osób, sprawujących wspólnie naczelną władzę w państwie poprzez wykonywanie funkcji ceremonialnych i formalnych. Ich kompetencje są zapisane z reguły w konstytucjach i ustawach zwykłych. Nie można uznać bezdyskusyjnie, w których państwach mamy do czynienia z funkcjonowaniem głowy państwa w formie wieloosobowej. Największe wątpliwości w tym aspekcie można mieć co do pozycji ustrojowej szwajcarskiej Rady Federalnej i jej przewodniczącego. Dlatego konieczna była próba przeanalizowania tego problemu.

Można wskazać na istnienie pewnego rodzaju prawidłowości. Obecnie istnieją dwa typy kolegialnej głowy państwa: te, w których członkowie są

1 Wedle definicji R. Herbuta, głowa państwa to osoba, która ze względu na wykonywanie szeregu formalnych i niejednokrotnie ceremonialnych funkcji stoi na czele danego państwa. B. Dziemidok formułuje definicję naczelnego organu w państwie następująco: głowa państwa jest to jednoosobowy (niekiedy kolegialny), naczelny organ państwa, sprawujący szereg formalnych i niejednokrotnie ceremonialnych funkcji.

Bardzo często w literaturze naukowej i publicystyce istnieje niejednoznaczność w formułowaniu definicji głowy państwa. Bowiem można ją rozumieć jako osobę (grupę osób) pełniącą najważniejszą konstytucyjnie funkcję w państwie (najwyższy organ w państwie wskazany przez przepisy konstytucyjne tj. najwyższy organ państwowych de iure), ale też jako osobę (grupę osób), która wbrew postanowieniom konstytucji sprawuje najwyższą władzę (najwyższy organ państwowy de facto). B. Dziemidok, Głowa państwa, w: Encyklopedia politologii, t. 2: Ustroje państwowe, red. W. Skrzydło, M. Chmaj, Zakamycze 2000, s. 123-124; R. Herbut, Głowa państwa, w: Leksykon politologii, red. A. Antoszewski, R. Herbut, Wrocław 2004, s. 118-119. 
równi względem siebie (Andora, San Marino) oraz te, w których członkowie stanowią kolegium na czele z przewodniczącym (który jest jednak primus inter pares względem pozostałych członków). Ponadto można postawić tezę, że o funkcjonowaniu w systemie politycznym kolegialnej głowy państwa zdecydowały czynniki historyczne, federacyjny ustrój państwa albo reżim autokratyczny panujący w danym państwie. Przedmiotem artykułu są państwa, w których głowa państwa funkcjonuje w oparciu o jedną z dwóch pierwszych determinant. Funkcjonowanie kolegialnej głowy państwa w państwach autokratycznych wymaga osobnego podjęcia problemu.

Można założyć, że część ustrojodawców państw posiadających w swoim systemie politycznym instytucję kolegialnej głowy państwa kierowała się wolą zminimalizowania ryzyka wprowadzenia dyktatury przez jednostkę stojącą na czele państwa. Wobec tego, kolegialnej głowie państwa można było pozostawić szeroki zakres władzy. Ryzyko bowiem, że kilka osób bez porozumienia ze sobą przejmie pełnię władzy, jest dużo mniejsze.

T. Słomka w artykule Głowa państwa w europejskich systemach politycznych (wybrane problemy) wspomina o trzech europejskich państwach, których elementem ustroju politycznego jest kolegialna głowa państwa. Wskazuje na funkcjonowanie tego organu w Andorze, San Marino oraz Bośni i Hercegowinie, odmawiając prawa obecności w tym gronie Szwajcarii $^{2}$. Wydaje się jednak, że do kategorii państw, w których mamy do czynienia z kolegialną głową państwa, należy zaliczyć wszystkie cztery państwa, rozszerzając tym samym listę państw wskazanych przez T. Słomkę.

Za kolegialną głowę państwa należy uznać każdy rodzaj głowy państwa, który jest niejednoosobowy, co oznacza, że do tej grupy będą zaliczane z jednej strony kilkuosobowe głowy państwa (z czym mamy do czynienia obecnie w Szwajcarii, a wcześniej w państwach realnego socjalizmu), ale i dwuosobowe głowy państwa (które funkcjonują w systemach politycznych San Marino i Andory).

\section{Funkcjonowanie kolegialnej głowy państwa w historii}

Na czele pierwszych państw stała jednostka. Owa konstrukcja władzy w oczywisty sposób miała doprowadzić do podejmowania szybkich decy-

2 T. Słomka, Głowa państwa w europejskich systemach politycznych (wybrane problemy), „Politeja” 2007, nr 1(7). 
zji w obliczu zagrożenia głównie ze strony obcych (starożytna monarchia egipska, babilońska, perska). Początek XVIII wieku przyniósł znaczny wzrost liczby państw, które opierały swój system polityczny na republikańskiej formie państwa. Obecnie mamy do czynienia z 45 monarchiami na niecałe 200 państw, co oznacza, że forma republikańska jest swego rodzaju standardowym modelem funkcjonowania państwa we współczesnym świecie. Literatura wskazuje najczęściej, że początkami instytucji współczesnej formy głowy państwa wybieranej na określoną kadencję (czyli nie dożywotnio) są Stany Zjednoczone Ameryki. W Europie ustrój republikański, na czele którego stoi jednoosobowa głowa państwa wywodzi się z Francji (druga połowa XIX wieku). Rozwój instytucji jednoosobowej głowy państwa $\mathrm{w}$ republikach miał miejsce przede wszystkim w XX wieku.

Za pierwszy przykład kolegialnej głowy państwa można uznać rządy dwóch królów w Sparcie. Sprawowali oni swój urząd w sposób kolegialny i bez zgody obu monarchów nie mogła zostać podjęta żadna decyzja. Władza była przekazywana w sposób dziedziczny. Wchodzili oni w skład Geruzji (Rady Starszych - organu przedstawicielskiego wspólnot rodowych w Sparcie). Działalność monarchów była kontrolowana przez Radę Starszych $^{3}$. Pełnili również funkcje religijne: składali ofiary bóstwom w imieniu Spartan. Kolegialność głowy państwa miała zapewnić wówczas zabezpieczenie przed wzrostem siły w którymś z ośrodków władzy ${ }^{4}$.

Początków kolegialnej głowy państwa można również szukać w czasach rozkwitu rzymskiej republiki. Na jej czele stało dwóch równych względem siebie konsulów wybieranych przez Komicja Centurialne. Gdy roczna kadencja upłynęła, obaj konsulowie (już jako prokonsulowie) udawali się na prowincje państwa, gdzie w imieniu swoich następców (kon-

3 Królowie mieli prawo wypowiadania wojny (gdyby ktoś ośmielił się sprzeciwić rozkazom monarchów groziła mu za to klątwa). Królowie posiadali prawo zarządzania publicznymi drogami, a także prawo decydowania w sprawach cywilnych swoich obywateli: „wyłącznie królowie wyrokują [w sprawie] kogo ma poślubić dziewica, która dziedziczy cały majątek po ojcu, jeżeli ojciec już jej nie zaręczył". Cytat za: Herodot, Dzieje, Księga VI Erato, w: Historia państwa i prawa - wybór tekstów źródtowych, B. Lesiński, Poznań 1995, s. 16.

${ }^{4}$ Zwraca na to uwagę G. Górski: „kolegialność urzędów chronić miała instytucje demokratyczne przed możliwością ich obalenia przez dyktatorów. Aby te gwarancje mieć, uznawano, iż warto nawet zapłacić cenę w postaci mniejszej sprawności $[\ldots]$ urzędów kolegialnych". Cyt.: G. Górski, Ewolucja ustroju w Rzymie, w: Historia ustrojów państw, red. G. Górski, S. Salmanowicz, Warszawa 2001, s. 52. 
sulów) wykonywali decyzje, jakie zapadały w Rzymie. Osoby pełniące najwyższy urząd w państwie miały zakaz piastowania tej funkcji dłużej niż rok oraz zakaz sprawowania urzędu rok po roku. Kolegium konsulów było urzędem stanowiącym niejako substytut urzędu króla w funkcjonującym wcześniej ustroju monarchicznym. Powstanie tego urzędu jest związane z obaleniem monarchii i ustanowieniem ustroju republikańskiego w 509 roku p.n.e., choć nazwa konsul pojawiła się dopiero kilkaset lat później. Jako pierwsi ten urząd objęli inspiratorzy obalenia monarchii - Lucius Tarquinius Collatianus i Lucius Iunius Brutus. Od tego czasu najwyższy urząd w państwie sprawowany był przez reprezentantów dużych rodów arystokratycznych ${ }^{5}$.

Konsulowie mieli szerokie uprawnienia. Polibiusz pisał o nich: „póki z legionami nie wyruszą w pole i póki bawią w Rzymie, decydują o wszystkich sprawach publicznych. Bo wszyscy inni urzędnicy, z wyjątkiem trybunów ludowych, są im podwładni i słuchają ich; a do senatu oni wpro-

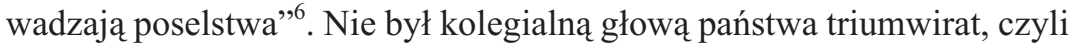
porozumienie trzech czołowych polityków rzymskich piastujących najwyższe funkcje państwowe w Rzymie ${ }^{7}$.

5 Miało to miejsce do 444 r. p.n.e., kiedy to trybun Kanulejusz wnioskował o dopuszczenie biedniejszej klasy - plebejuszy. Doprowadziło to do sytuacji na początku II wieku p.n.e., w której urząd pełniło jednocześnie dwóch plebejuszy.

${ }^{6}$ Cytat za: Polibiusz, Dzieje, Księga VI, w: Historia państwa i prawa-wybór tekstów..., op. cit., s. 20.

W zakresie władzy administracyjnej konsulowie mogli wydawać rozporządzenia i egzekwować ich stosowanie. W zakresie władzy ustawodawczej przysługiwało im prawo przewodniczenia, zwoływania i wykonywania uchwał ciał reprezentacyjnych, a także prawo inicjatywy prawodawczej w tych ciałach. Każdemu z konsulów przysługiwało prawo weta w stosunku do decyzji drugiego konsula. Z racji przejęcia urzędu głowy państwa przez konsulów, powstał problem z realizacją części uprawnień religijnych, które wcześniej przysługiwały królom rzymskim. Doszło wówczas do automatycznego transferu uprawnień monarszych na konsulów: przewodniczyli oni uroczystościom religijnym, a także brali udział w auspicjach. Konsulowie mieli prawo przeprowadzania poboru żołnierzy i dowodzenia wojskiem rzymskim, prawo wyznaczania dowódców, a także prawo degradacji podwładnych oficerów. W ramach kompetencji sądowniczych sprawowali oni nadzór nad sprawami karnymi i cywilnymi.

7 Mieliśmy do czynienia z dwoma triumwiratami w historii starożytnego Rzymu. Pierwszy zawiązany triumwirat był przez Gajusza Juliusza Cezara, Gnejusza Pompejusza i Marka Krassusa. Istniał do 53 p.n.e., do śmierci Krassusa podczas wojny z Partami. Drugi triumwirat został powołany przez Marka Antoniusza, Oktawiana Augusta oraz Marka Lepidusa. 
Innym regionem, w którym ukształtowała się kolegialna głowa państwa w starożytności była Kartagina. Chociaż de facto władza spoczywała w rękach oligarchii, to formalnie najwyższy urząd sprawowało dwóch sufetów (łac. suffetes) ${ }^{8}$.

Pierwszym, spośród państw będących zasadniczym tematem niniejszego artykułu, w którym doszło do ukształtowania się kolegialnej głowy państwa, była Republika San Marino. Chociaż wczesnośredniowieczna historia polityczna tego państwa nie jest dobrze udokumentowana, to wiadome jest, że powstała wówczas wspólnota, która ponad wszystko ceniła swoją wolność. Najprawdopodobniej wtedy też funkcjonowała istniejąca do dzisiaj formuła głowy państwa - Regencja. Pierwszymi Kapitanami-Regentami (wówczas jeszcze konsulami) ${ }^{9}$, którzy zostali odnotowani w historii byli Oddone Scarito i Filippo da Sterpeto ${ }^{10}$. Większość źródeł wskazuje na dwie determinanty kształtujące taką, a nie inną formę głowy państwa. Pierwszą jest wzorowanie się na instytucji rzymskich konsulów, drugim - legenda mówiąca o tym, że aby zapobiec koncentracji władzy w jednej osobie, Święty Marinus rozdzielił najwyższą władzę w Republice na dwie osoby.

Omawiany organ początkowo posiadał bardzo duże kompetencje (w szczególności w zakresie władzy sądowniczej i administracyjnej). Stopniowo były one ograniczane z jednej strony na rzecz suwerena (Arengo) lub jego reprezentację - Wielką Radę Generalną, oraz z drugiej strony - na rzecz innych organów państwowych (w szczególności Kongres Państwa i sądy Republiki).

Jednym z pierwszych źródeł pisanych, jakie stoją u podstaw historii ustroju politycznego Andory, jest pochodzący z 860 roku akt konsekracji

8 Sufeci sprawowali swój urząd przez rok (podobnie jak konsulowie rzymscy). Byli oni wybierani przez zgromadzenie obywateli, a kontrola nad nimi była sprawowana również przez samych obywateli i inne organy wybierane przez lud Kartaginy. Władza sufetów polegała przede wszystkim na sprawowaniu funkcji sędziów i kapłanów. Byli oddzieleni od władzy wojskowej, co jednak nie przeszkadzało wielu z nich być wodzami. Kartagina $i$ wojny punickie, http://www.historica.pl/index.php?action=forumWiecej\&dzial_id=16\&id=414651\&section=rzym\&page=5, dostęp 24.03.2010 r.

9 Nazwa głowy państwa w San Marino ewoluowała: do XIII wieku regentów nazywano konsulami, potem różnicowano regentów na kapitana (reprezentującego klasę arystokratyczną) i obrońcę (reprezentującego ludność wiejską). Współczesna nazwa regentów wywodzi się z XIV wieku.

10 S. Stępnicki, System polityczny „Najjaśniejszej Republiki San Marino”, Warszawa 2004, s. 16-19. 
katedry w Urgell. Panujący na ziemi Urgell hrabiowie frankońscy przyczynili się do znacznego rozwoju gospodarczego tego niewielkiego skrawka Pirenejów. W 1133 roku hrabia francuski Ermengol VI przekazał wszystkie swoje posiadłości biskupowi Urgell, którym był wówczas Pere Berenger. Hrabia poprosił również mieszkańców, aby złożyli biskupowi hołd ${ }^{11}$. 8 września 1278 roku biskup Urgell, Pere d’Urg oraz hrabia Foix, Roger Bernat III, zawarli układ (Pareatge), który miał potwierdzić równość praw i posiadania dwóch panów feudalnych nad jednym lennem - Andorą. Na mocy tego i kolejnych układów, umocniła się konstrukcja współksiążąt andorskich jako głowy państwa ${ }^{12}$.

Okres średniowiecza i czasy wczesnonowożytne nie owocowały w duże rozpowszechnienie modelu kolegialnej głowy państwa wśród ówczesnych systemów politycznych: na czele monarchii wczesnofeudalnej (państwa germańskie i słowiańskie), podobnie jak i monarchii feudalnej, a także monarchii stanowej czy innej formy państwa, stały jednostki: król, książę, wódz, cesarz, kalif lub sułtan.

Jak zauważa Sebastian Stępnicki, wiek XVII i XVIII były najtrudniejszym okresem w dziejach Andory. Za panowania króla Henryka IV dało się zauważyć, że ten monarcha, jako współksiążę Andory, ograniczył swoje zainteresowanie Księstwem, a kiedy w 1608 r. sami Andorczycy poprosili Henryka IV o interwencję, monarcha ograniczył się jedynie do przysłania hrabiego Carenay, który miał go reprezentować. W ten sposób nieoficjalnie ustanowiona została instytucja stałego delegata współksięcia francuskiego, którą ujęto w ramy formalne dopiero pod koniec XIX wieku. Dużą zmianę dla konstrukcji kolegialnej głowy państwa w Andorze przyniosła Wielka Rewolucja Francuska i wydarzenia będące jej następstwem. W 1793 roku zbiegły się dwa wydarzenia: konieczność wpłacenia przez Andorczyków specjalnego podatku do budżetu państwa francuskiego oraz wykonanie wyroku śmierci na monarsze francuskim, Ludwiku XVI. Jako, że ów podatek uznawano za przejaw feudalizmu, to rząd francuski daniny nie przyjął. Niestety, wraz z rewolucją Andorczycy utracili szereg przywilejów, które wcześniej im przysługiwały. Wystapie-

\footnotetext{
11 Przekazanie władzy zostało potwierdzone potem jeszcze dwa razy: w 1186 i 1199 roku.

12 P. Osóbka, Współczesny system polityczny Księstwa Andory, Opole-Toruń 2003-2006, s. 15-16. Opracowanie dostępne na stronie internetowej Biblioteki Elektronicznej Wydawnictwa Adam Marszałek: http://www.marszalek.com.pl/index.php?m=7, dostęp 11.01.2011 r.
} 
nie ludu francuskiego z 1789 roku doprowadziło do sytuacji, w której Andorczycy mieli tylko jednego współksięcia. Zmieniło się to w 1806 roku, kiedy to Napoleon Bonaparte przywrócił stosunki francusko-andorskie.

W latach 30. XX wieku w Andorze miały miejsce częste konflikty między parlamentem a głową państwa. Uczestniczyli w tym sporze delegaci współksiążąt. Po II wojnie światowej doszło do kolejnego konfliktu, w którym stronami byli tym razem Rada Generalna i wikariusze współksiążąt. Doszło wówczas do przedstawiania pierwszych pomysłów dotyczących debaty konstytucyjnej. W 1981 roku po raz pierwszy powołano osobny organ odpowiedzialny za wykonywanie uchwał Rady Generalnej - Radę Wykonawczą ${ }^{13}$. Na początku lat 90. doprowadzono do zmian w ustroju państwa tak by jasno rozgraniczyć kompetencje organów państwa.

Współczesnej koncepcji kolegialnej głowy państwa należy poszukiwać pod koniec XVIII wieku, kiedy to od 1795 roku w ustroju I Republiki Francuskiej funkcjonował Dyrektoriat stanowiący kolegialną, pięcioosobową głowę państwa. Decyzje w tym organie były podejmowane „kolegialnie, a co trzy miesiące zmieniał się jeden z dyrektorów jako przewodniczący obradom. Szereg szczegółowych przepisów miało zapobiec aspiracjom dyktatorskim dyrektorów"14. Wyborów dyrektorów dokonywała Rada Starszych (jedna z izb francuskiego parlamentu) spośród dziesięciu kandydatów, przedstawianych przez Radę Pięciuset. Kandydaci musieli mieć przynajmniej 40 lat, a członkami mogli zostać jedynie byli deputowani do parlamentu lub byli ministrowie. Kolejny wybór był możliwy dopiero po upływie pięciu lat. Sami dyrektorzy nie byli odpowiednikami dzisiejszych ministrów, ale stanowili naczelny organ państwowy. Ministrowie byli zwykłymi urzędnikami (podporządkowanymi Dyrektoriatowi) odpowiedzialnymi za poszczególne resorty: ministrowie byli odpowiedzialni zarówno za niewykonywanie ustaw, jak i też za niewykonywanie zarządzeń Dyrektoriatu ${ }^{15}$. Obradom Dyrektoriatu przewodniczył jeden z dyrektorów (kolejno przez trzy miesiące). Podstawowym zadaniem organu było czuwanie nad bezpieczeństwem zewnętrznym i wewnętrznym państwa. Dyrektoriat mógł wydawać rozporządzenia w celu wykonywania ustaw. Ponadto przysługiwało mu ograniczone prawo dysponowania wojskiem $^{16}$.

13 Ibidem, s. 17-27.

14 Cyt.: G. Górski, S. Salmonowicz, Historia ustrojów państw..., op. cit., s. 450.

15 Konstytucja Republiki Francuskiej z 22 VIII 1795 roku, art. 152.

16 Ibidem, art. 133-150. 
System Dyrektoriatu upadł w 1799 roku. W grudniu tego roku Napoleon Bonaparte proklamował nową konstytucję, którą naród francuski przyjął w plebiscycie. Zgodnie z konstytucją konsularna, w miejsce Dyrektoriatu pojawił się ustrój konsularny. Fundamentem tego ustroju był trzyosobowy organ stanowiący kolegialną głowę państwa - Konsulat. Zgodnie z art. 39 Konstytucji Republiki Francuskiej z 1799 roku, sprawowanie władzy wykonawczej zostało powierzone trzem konsulom mianowanym na kadencję dziesięcioletnią ${ }^{17}$. Zgodnie z ustawą zasadniczą, mogli oni zostać ponownie wybrani bez żadnych ograniczeń. Konsulowie drugi i trzeci posiadali głos doradczy, a Pierwszy Konsul miał prawo ogłaszania ustaw, powoływania ministrów oraz ambasadorów ${ }^{18}$. Po zmianach ustrojowych, które miały miejsce w 1802 roku, Napoleon Bonaparte został dożywotnim konsulem. W 1804 roku funkcje Pierwszego Konsula przeszły na Cesarza, którym został Napoleon.

Kolejnym państwem, w którym pojawiła się kolegialna głowa państwa jest Szwajcaria. W myśl przepisów pierwszej, suwerennie przyjętej, konstytucji szwajcarskiej (1848) zaczęła funkcjonować Rada Federalna. Była to siedmioosobowa głowa państwa, wybierana przez obie izby parlamentu. Spośród nich była wybierana jedna osoba (na rok), która koordynowała prace organu. Nie spełniała ona jednak żadnych innych funkcji niż te, które przysługiwały jej z racji przewodzenia kolegialnej głowie państwa.

17 Konstytucja Republiki Francuskiej z 13 grudnia 1799 roku, art. 39. Konstytucja z nazwiska wymieniała osoby będące członkami Konsulatu: „Konstytucja mianuje Pierwszym Konsulem obywatela Bonaparte, byłego konsula tymczasowego; Drugim Konsulem - obywatela Cambaceres, byłego konsula tymczasowego; Trzecim Konsulem - obywatela Lebrun, byłego członka komisji Rady Starszych. - Tym razem Trzeci Konsul jest mianowany tylko na 5 lat". Cyt.: ibidem.

18 Nie oznaczało to jednak, że Pierwszy Konsul sam był głową państwa, gdyż Konsulat jako kolegium utrzymywał stosunki międzynarodowe, prowadził rokowania, zawierał wszystkie traktaty pokoju, przymierza, zawieszenia broni, neutralności, traktaty handlowe i inne umowy międzynarodowe, a także, zgodnie z art. 47 Konstytucji Republiki, dbał o bezpieczeństwo wewnętrzne i obronę państwa na zewnątrz oraz decydował o dowodzeniu siłami zbrojnymi i morskimi. Niemniej, to Pierwszy Konsul sprawował władzę de facto dyktatorską, gdyż jego decyzja nie wymagała dla swej ważności zgody pozostałych członków Konsulatu. Ponadto, to tylko przed nim odpowiadali ministrowie (a nie przed całą kolegialną głową państwa). Rząd złożony z konsuli miał za zadanie formułowanie projektów ustaw, wydawanie do nich aktów wykonawczych, zajmowanie się bieżącą kontrolą dochodów i wydatków państwa, a także przede wszystkim jako głowa państwa: dbanie o bezpieczeństwo wewnętrzne i zewnętrzne państwa poprzez dowodzenie siłami zbrojnymi, utrzymywanie stosunków międzynarodowych, prowadzenie rokowań, podpisywanie i zawieranie traktatów. 
Kadencja organu wynosiła początkowo trzy lata ${ }^{19}$. Konstytucja stanowiła, że obrady Rady mogły się odbyć, jeżeli uczestniczyło w nich co najmniej 4 członków. Do najważniejszych kompetencji organu należało: kierowanie sprawami federalnymi (w ramach ustaw i dekretów), kierowanie do parlamentu wniosków składanych przez kantony, zapewnianie przestrzegania konstytucji kantonalnych, czuwanie nad przebiegiem wyborów i bezpieczeństwem federacji, odpowiadanie za budżet państwa, sprawowanie nadzoru nad wszystkimi urzędnikami federalnymi i pracownikami administracji federalnej, a także składanie sprawozdań i raportów parlamentowi.

Rada pełniła również funkcje reprezentacyjne oraz kierownicze w stosunku do całej federacji. Jako organ stojący na czele państwa, Rada Federalna musiała posiadać skład odpowiadający różnorodności etnicznej i religijnej Szwajcarów. Dlatego czterech członków reprezentowało kantony niemieckie, dwóch - francuskie, a jeden - włoskie. Ponadto, istniała zasada, wedle której w tym siedmioosobowym organie musieli zasiadać przedstawiciele kantonów Berno, Zurych i Vaud. W 1874 roku dokonano całkowitej nowelizacji konstytucji, ale nie zmieniło to pozycji ustrojowej omawianego organu. W okresie 1874-1999 doprowadzono do przyjęcia aż 128 nowelizacji ustawy zasadniczej. Również one nie zmieniły wiele w konstytucyjnej pozycji Rady Federalnej.

W XX wieku doszło do znaczącej zmiany w ustroju politycznym Republiki San Marino. W 1906 roku doszło do spotkania 802 przedstawicieli głów rodzin, na którym zdecydowano o przekazaniu parlamentowi całości kompetencji Arengo. Drugą zmianą, dużo istotniejszą dla tematu niniejszego opracowania, było wprowadzenie zakazu pełnienia urzędu głowy państwa przez 3 lata po zakończeniu kadencji.

Ostatnim państwem, którego historię ustroju politycznego należałoby zarysować jest federacja bośniacko-horwacka.

Obecny ustrój polityczny Republiki Bośni i Hercegowiny jest przede wszystkim wypadkową wydarzeń, które miały miejsce na Bałkanach pod koniec lat 90. XX wieku. W 1992 roku doszło do oddzielenia się Bośni i Hercegowiny od państwa jugosłowiańskiego: przeprowadzono referendum, w którym opowiedziano się za powstaniem odrębnego państwa postjugosłowiańskiego - Bośni i Hercegowiny. Trzy lata później doszło do słynnego porozumienia z Dayton, które doprowadziło do pokoju między republikami jugosłowiańskimi, a przez to i do ostatecznego wykrystalizowa-

19 Zmiany dokonano 20 czerwca 1931 roku w referendum, w którym wydłużono kadencję Rady Federalnej $\mathrm{z}$ owych 3 do 4 lat. 
nia się systemu politycznego Bośni i Hercegowiny, którego centralnym elementem wydaje się być Prezydium (Prezydencja) Republiki Bośni i Hercegowiny.

Po przemianach z przełomu lat 80. i 90., w 1993 roku, przygotowano projekt Konstytucji Republiki Bośni i Hercegowiny, w której utrzymano formułę wieloosobowej głowy państwa ${ }^{20}$. Zgodnie z nią, Prezydium (nazywane w ustawie zasadniczej później Prezydencją) miało składać się z siedmiu członków, na czele którego stać miał Przewodniczący. Pojawił się również pomysł utworzenia urzędów prezydenta i wiceprezydenta (wybieranych w wyborach powszechnych), jednak został on odrzucony przez Serbów. Formuła, według której kreowana była bośniacko-hercegowińska głowa państwa została ostatecznie zatwierdzona w Dayton.

Należy przy tym zauważyć, że Republika Bośni i Hercegowiny jest federacją o stosunkowo dużym poziomie decentralizacji. Można stwierdzić, że Bośnia i Hercegowina jest luźną federacją dwóch państw (co może ewentualnie doprowadzić w przyszłości do podziału państwa na dwa niezależne byty: Federację Chorwacko-Muzułmańską oraz Republikę Serbską) $)^{21}$. Same republiki wchodzące w skład federacji są podmiotami na tyle niezależnymi, że posiadają własne konstytucje, rządy, policję, samodzielność m.in. w sprawach sprawiedliwości i gospodarki ${ }^{22}$.

\section{Podstawy konstytucyjne pozycji ustrojowej kolegialnej głowy państwa we współczesnych państwach demokratycznych}

Pakt Pareatge, co zostało już wcześniej podkreślone, stał się fundamentem konstytucyjnej konstrukcji andorskiej głowy państwa, która obecnie

20 Głowa państwa, której elementami są przedstawiciele kilku różnych narodowości i wyznań religijnych, nie jest w historii ustroju Bośni i Hercegowiny zjawiskiem nowym. Historia kolegialnej głowy państwa w tym państwie sięga roku 1974, kiedy to ustawa zasadnicza Socjalistycznej Republiki Bośni i Hercegowiny, wprowadziła dziewięcioosobowe Prezydium. Należy jednak nie zapominać, że już po pierwszych wolnych wyborach w 1990 roku w skład organu wchodziło jedynie siedem osób: dwóch Bośniaków, dwóch Serbów, dwóch Chorwatów i jeden członek reprezentujący pozostałe mniejszości. Chronology of the Presidency of BiH, http://www.predsjednistvobih.ba/hron/?cid=74,1,1, dostęp 10.10.2010 r.

${ }_{21}$ M. Tanty, Bałkany w XX wieku. Dzieje polityczne, Warszawa 2003, s. 355.

22 W 2005 roku władze Bośni i Hercegowiny utworzyły zunifikowane siły zbrojne. B. Balcerowicz, Armie państw małych Europy, w: Małe państwa Europy. Specyfika systemu politycznego i aktywności międzynarodowej, red. D. Popławski, Warszawa 2009, s. 155. 
składa się z współksięcia francuskiego oraz współksięcia hiszpańskiego (episkopalnego). Za tego pierwszego należy uważać wybranego w wyborach powszechnych prezydenta Republiki Francuskiej ${ }^{23}$. Natomiast drugim współksięciem jest z urzędu każdy biskup diecezji Urgell ${ }^{24}$. Zasada równości członków kolegialnej głowy państwa została podniesiona do konstytucyjnej, i tak art. 43 ust. 2 stanowi, że uprawnienia współksiążąt są równe, a współksiążęta powinni dysponować budżetem na takim samym poziomie ${ }^{25}$.

Ustawa zasadnicza Andory określa ustrój tego księstwa jako parlamentarne współksięstwo ${ }^{26}$. Art. 44 Konstytucji Księstwa stanowi, że współksiążęta są symbolem i gwarantem trwałości i ciagłości Andory, jak również jej niepodległości oraz utrzymania tradycyjnego ducha równości w relacjach z państwami sąsiednimi ${ }^{27}$. Każdy z współksiążąt jest zobowiązany do złożenia przysięgi lub potwierdzenia przestrzegania wykonywania swoich obowiązków zgodnie z ustawą zasadniczą. Należy podkreślić, że do uchwalenia pierwszej w dziejach księstwa ustawy zasadniczej, głowa państwa dysponowała teoretycznie władzą nieograniczoną ${ }^{28}$.

Od połowy XI wieku do dzisiaj, 114 biskupów zarządzało diecezją Seu d'Urgell, z czego 63 stało (wraz z współksięciem francuskim) na czele państwa andorskiego ${ }^{29}$. Natomiast jeżeli chodzi o drugi człon głowy państwa, to Andora posiadała 53 francuskich współksiążąt ${ }^{30}$.

Regencja jest najwyższym gwarantem porządku konstytucyjnego Republiki San Marino ${ }^{31}$. Obecnie, od 1 października 2010 roku, na czele

23 Należy zauważyć, że sama ustawa zasadnicza ani ustawy zwykłe nie regulują jak ów współksiążę ma zostać wybrany. Dlatego też można sprowadzić to do konstatacji, zgodnie z którą obywatele francuscy posiadający czynne prawo wyborcze uczestniczą w wyborze nie tylko głowy państwa francuskiego, ale członka głowy państwa - sąsiada. P. Osóbka, Systemy konstytucyjne Andory, Liechtensteinu, Monako, San Marino, Warszawa 2008, s. 8-9.

24 Również w przypadku tego członu andorskiej głowy państwa.

25 Konstytucja Księstwa Andory, art. 43 ust. 2 i art. 47.

26 Ibidem, art. 1 ust. 4.

27 P. Osóbka, Współczesny system polityczny Księstwa..., op. cit., s. 71.

28 Ibidem.

29 W 2003 roku, po ponad trzydziestoletnich rządach biskupa Joana Martí Alana, diecezję Seu d'Urgell objął Joan Enric Vives i Sicilia. Episcopologi, http://www.bisbaturgell.org/index.php?option=com_content\&view=article\&id=24\&Itemid=56\&lang=ca, dostęp 10.10.2010 r.

${ }^{30}$ Obecnym współksięciem francuskim jest Nicolas Sarkozy, który urząd prezydenta Republiki Francuskiej objął w 2007 roku.

31 Ustawa kwalifikowana nr 186 z 16 grudnia 2005 roku o Kapitanach-Regentach, art. 2 ust. 1. 
państwa stoją: Giovanni Francesco Ugolini ${ }^{32}$ i Andrea Zafferani. Ich kadencja upłynie 31 marca 2011 roku.

Pozycję ustrojową Rady Federalnej reguluje Konstytucja Konfederacji Szwajcarskiej z 1999 roku. Obecnymi członkami Rady Federalnej są: Didier Burkhalter, Eveline Widmer-Schlumpf, Johann Schneider-Ammann, Doris Leuthard, Micheline Calmy-Rey, Simonetta Sommaruga, Ueli Maurer. Na czele Rady Federalnej stoi obecnie Micheline Calmy-Rey. Jej zastępcą jest Eveline Widmer-Schlumpf ${ }^{33}$.

Funkcję głowy państwa pełni w Bośni i Hercegowinie trzyosobowe Prezydium (Prezydencja) Republiki Bośni i Hercegowiny. Skład Prezydencji został precyzyjnie określony w Konstytucji Bośni i Hercegowiny z 1995 roku $^{34}$, wedle której Prezydencja składa się z trzech członków: Bośniaka i Chorwata, każdego wybieranego z terytorium Federacji oraz jednego Serba bezpośrednio wybieranego z terytorium Republiki Serbskiej ${ }^{35}$.

Od 10 listopada 2010 roku w skład Prezydium wchodzą: Bakir Izetbegović (Bośniak), Nebojša Radmanović (Serb) i Željko Komšić (Chorwat). Aktualnym Przewodniczącym Prezydium jest Nebojša Radmanović ${ }^{36}$, który sprawuje ten urząd po raz trzeci ${ }^{37}$. Jest to skład Prezydium piątej kadencji $^{38}$.

Obecną pozycję ustrojową sanmaryńskiej głowy państwa - Regencji, określają: ustawa z dnia 8 lipca 1974 roku nr 59 - Deklaracja praw obywateli oraz fundamentalnych zasad porząaku San Marino, ustawa konstytucyjna nr 185 z 16 grudnia 2005 roku o Kapitanach-Regentach, ustawa kwalifikowana nr 186 z 16 grudnia 2005 roku o Kapitanach-Regentach, ustawa $\mathrm{nr} 15$ z 24 marca 1945 roku o reformie systemu wyborczego Kapitanów-Regentów oraz ustawa kwalifikowana nr 55 z 25 kwietnia 2003 roku o organizacji, funkcjonowaniu, formach działania i procedurach oraz o skutkach decyzji Kolegium Gwarancyjnego w sprawie konstytucyjności przepisów.

${ }^{32}$ Giovanni Francesco Ugolini był już wcześniej Kapitanem-Regentem. Urząd ten pełnił od 1 kwietnia do 30 września 2002 roku wraz z Antonio Lazzaro Volpinarim.

${ }^{33}$ Stan na 27.03.2011 r.

34 Konstytucja Bośni i Hercegowiny została przyjęta jako załącznik nr 4 do porozumienia z Dayton (The General Framework Agreement for Peace in Bosnia and Herzegovina). Porozumienie wraz z załącznikami dostępne: The General Framework Agreement, http://www.ohr.int/dpa/default.asp?content_id=380, dostęp 13.10.2010 r.

35 Konstytucja Bośni i Hercegowiny z 1995 roku, art. 4 . Funkcjonowanie głowy państwa w Bośni i Hercegowinie określa art. 5 aktualnej Konstytucji Bośni i Hercegowiny.

${ }^{36}$ Stan na 27.03.2011 r.

${ }^{37}$ Kadencje Nebojšy Radmanovića jako Przewodniczącego Prezydium to: 6.11.2006-6.07.2007, 6.11.2008-6.07.2009 i obecnie od 10.11.2010 r.

38 Chronology of the Presidency of..., op. cit., dostęp 11.11.2010 r. 
Nie należy zapominać o funkcjonowaniu w ustroju politycznym Bośni i Hercegowiny jeszcze jednego podmiotu. Jest nim Urząd Wysokiego Przedstawiciela dla Bośni i Hercegowiny (Office of the High Representative in Bosnia and Herzegovina) ${ }^{39}$. Jego najważniejsze uprawnienie zostało określone na konferencji w Bonn (1997). Uzgodniono tam, że ma on prawo do odwoływania ze stanowisk urzędników państwowych, których zachowanie mogłyby utrudniać wdrażanie w Republice procesu pokojowego $^{40}$. Pozycję ustrojową tego Urzędu należy uznać za zdecydowanie silną $^{41}$. Nie pełni on jednak funkcji reprezentacji Bośni i Hercegowiny $\mathrm{w}$ stosunkach $\mathrm{z}$ innymi podmiotami ${ }^{42}$.

39 Urząd ten został powołany w oparciu o Układ (Porozumienie) z Dayton z 1995 roku (aneks 10). Reprezentuje on społeczność międzynarodową w Bośni i Hercegowinie. W 2002 roku obok Urzędu Wysokiego Przedstawiciela istnieje jeszcze Urząd Specjalnego Przedstawiciela Unii Europejskiej. Oba urzędy są sprawowane obecnie przez Valentina Inzko. Głównym celem Wysokiego Przedstawiciela jest nadzorowanie i kontrola implementacji cywilnych ustaleń z Dayton i Bonn.

Obsada urzędu i tryb jego działania regulowany jest przez Radę ds. Wdrażania Pokoju (Peace Implementation Council), ciało reprezentujące 55 podmiotów zainteresowanych utrzymaniem pokoju w Bośni. Jak słusznie zauważają W. Stanisławski i M. Szpala, Wysoki Przedstawiciel nie jest tym samym odpowiedzialny przed obywatelami Bośni i Hercegowiny. W. Stanisławski, M. Szpala, Bośniacki chaos. Źródła kryzysu politycznego we wspótczesnej Bośni i Hercegowinie, Prace Ośrodka Studiów Wschodnich, nr 31, Warszawa 2009, s. 22 i n.

${ }^{40}$ General Information - Office of the High Representative in Bosnia and Herzegovina, http://www.ohr.int/ohr-info/gen-info/, dostęp 15.10.2010 r.

${ }^{41}$ Można tutaj wskazać na sytuację z 2001 roku, kiedy to Wysoki Przedstawiciel usunął z urzędu Ante Jelavica, członka Prezydium. Sytuacja powtórzyła się w 2005 roku, kiedy Wysoki Przedstawiciel zdymisjonował Dragana Covica. Chronology of the Presidency..., op. cit., dostęp 16.11.2010 r.

42 T. Markiewicz wskazuje na rodzaje decyzji podejmowanych przez ten urząd w okresie 1998-2000: a) decyzje o charakterze systemowym: kwestia obywatelstwa, inwestycje zagraniczne, jednolite samochodowe tablice rejestracyjne, wspólna waluta, prowadzenie prywatyzacji, stworzenie komisji niezależnych mediów, prawo własnościowe, rozgłośnie państwowe, wolność prasy, restrukturyzacja federacyjnego Sądu Najwyższego, ochrona świadków, służba graniczna; b) decyzje o charakterze krótkoterminowym, czyli arbitraż w sporach politycznych: pakiet decyzji dotyczących Mostaru (prokuratura, sądy, status mniejszości, lotnisko), dowody osobiste dla osób przesiedlonych i uchodźców, udziały w prywatyzacji dla weteranów wojennych, miejsca spotkań rządu, procedury naboru do Międzynarodowych Sił Policji; c) decyzje o charakterze czysto symbolicznym: flaga, hymn narodowy, wzory umundurowania, wywieszanie flagi państwowej na oficjalnych instytucjach. T. Markiewicz, Ewolucja systemu politycznego Bośni i Hercegowiny, w: Bałkany u progu zjednoczonej Europy, Kraków 2008, s. 195. 


\section{Kompetencje kolegialnej glowy państwa we współczesnych państwach demokratycznych}

Konstytucje (i inne akty o charakterze ustrojowym) przyznają stosunkowo duży zakres władzy omawianym organom (por. tabela 1). Andorscy współksiążęta do 1993 roku dysponowali teoretycznie nieograniczoną władza, co zostało już wcześniej wskazane. P. Osóbka charakteryzując pozycję kolegialnej głowy państwa w Andorze, wskazuje, że współksiążęta pełnią rolę arbitrów i moderatorów funkcjonowania władz publicznych i instytucji politycznych Księstwa ${ }^{43}$.

S. Stępnicki wskazuje, że Regencja jest organem: konstytucyjnym, legislacyjnym i administracyjnym. Nie podlega wątpliwości, że głowa państwa nie posiada odpowiednich prerogatyw by rządzić samodzielnie i bezpośrednio, a jest organem reprezentacyjnym, który koordynuje prace sanmaryńskiego parlamentu i rządu. Choć posiada instrumenty, które pozwalają na zajmowanie się bieżącą polityką: Regencji przysługuje prawo wydawania tzw. dekretów regencyjnych. Głowa państwa wydaje owe akty w wyjątkowych przypadkach ${ }^{44}$. Wydawanie dekretów poprzedzone musi być opinią Kongresu Państwa. Dekret traci ważność, jeżeli w ciaggu trzech miesięcy nie zostanie przedstawiony parlamentowi do zatwierdzenia ${ }^{45}$.

Szwajcarska Rada Federalna, zgodnie z art. 174 szwajcarskiej ustawy zasadniczej, jest najwyższą władzą rządzącą i wykonawczą ${ }^{46}$. Oznacza to, że wykonuje ona wszystkie obowiązki zastrzeżone przez Konstytucję dla federacji, a pozostałe pozostawia władztwu kantonalnemu.

Jedną z naczelnych zasad ustroju Rady Federalnej jest jej kolegialność, wyrażona w art. 177 ust. 1 konstytucji. Teoretycznie oznacza to, iż każdy akt rządowy musi być potwierdzony sankcją Rady Federalnej (dyskusja, głosowanie wszystkich członków). W praktyce (choć również w zapisach konstytucji pojawia się taki zapis) doszło jednak do przekazania części uprawnień poszczególnym członkom rządu jako kierownikom departamentów (bardzo upraszczając, można przyjąć, że szwajcarskie departamenty na czele $\mathrm{z}$ radcami federalnymi to ministerstwa na czele

43 P. Osóbka, Współczesny system polityczny Księstwa..., op. cit., s. 71.

44 Ustawa z dnia 8 lipca 1974 roku nr 59 - Deklaracja praw obywateli oraz fundamentalnych zasad porządku San Marino, art. 3.

45 Ibidem.

46 Konstytucja Federalna Konfederacji Szwajcarskiej z 1999 roku, art. 174. 
z ministrami) ${ }^{47}$. Każdy z radców-ministrów odpowiada za inny dział federalnej administracji rządowej choć Rada Federalna za administrację federalną odpowiada wspólnie, zgodnie $\mathrm{z}$ naczelną zasadą tego organu - zasada kolegialności. W ustroju politycznym Szwajcarii nie istnieje popularna $\mathrm{w}$ demokracjach europejskich instytucja ministra bez teki.

Głowa państwa w Bośni i Hercegowinie podejmuje decyzje w drodze konsensusu. Jednak ustawa zasadnicza federacji przewiduje sytuację, w której jednomyślność nie jest możliwa. Wówczas decyzja może zostać podjęta przez dwóch członków Prezydencji ${ }^{48}$. Gdyby doszło do sytuacji, w której decyzja podjęta przez Prezydium jest uważana przez jej członka za destruktywną, może ją zakwestionować. Wówczas dochodzi do jej kontroli przez parlament krajowy (parlament odpowiedniej części federacji), który większością 2/3 głosów może decyzję zawetować ${ }^{49}$. Poza kompetencjami, które posiada Prezydencja in gremio, jej przewodniczący posiada również własne uprawnienia ${ }^{50}$.

W myśl art. 4 ust. 4 bośniacko-hercegowińskiej konstytucji, Zgromadzenie Parlamentarne jest odpowiedzialne za wprowadzanie w życie wszelkich decyzji, które są podejmowane przez Prezydium w celu realizacji postanowień ustawy zasadniczej. Ponadto, każdego roku Zgromadzenie Parlamentarne, na wniosek Prezydencji, przyjmuje budżet. Musi on obejmować wydatki niezbędne do realizacji zadań instytucji federacji oraz zobowiązań międzynarodowych tego państwa.

Prezydium uczestniczyło też w konsultacjach dotyczących kandydatów na członków zarządu banku centralnego federacji pierwszej kadencji. Ponadto, trzech członków miało być wskazanych przez głowę państwa. Obecnie, wszystkich pięciu członków jest wyznaczanych przez Prezydencję.

47 Wyróżnia się następujące departamenty: spraw zagranicznych, spraw wewnętrznych, spraw wojskowych, wymiaru sprawiedliwości i policji, finansów i ceł, gospodarki, komunikacji i energetyki.

48 Konstytucja Bośni i Hercegowiny..., op. cit., art. 5 ust. 2 pkt 3.

49 Ibidem, art. 5 ust. 2 pkt 4.

50 Z urzędu, przewodniczący Prezydencji: odpowiada za planowanie działań głowy państwa (opracowanie programu spotkań), zwołuje posiedzenia głowy państwa, podpisuje i ogłasza (promulguje) akty wynikające z działalności Prezydium, reprezentuje i-działając w imieniu Prezydencji - prezentuje stanowiska głowy państwa w ważnych kwestiach (w państwie i poza nim, w szczególności, gdy troje członków Prezydencji nie mogą wspólnie uczestniczyć). Głowa państwa przyjmuje również listy uwierzytelniające od ambasadorów, ale dopiero po tym jak Prezydencja in gremio uchwali zgodę na wyrażenie agrément. Rules of Procedure of the Presidency of $\mathrm{BiH}$ (1-02-01-285/01 September 14, 2001), art. 6. 
$\frac{\pi}{\frac{\pi}{0}}$

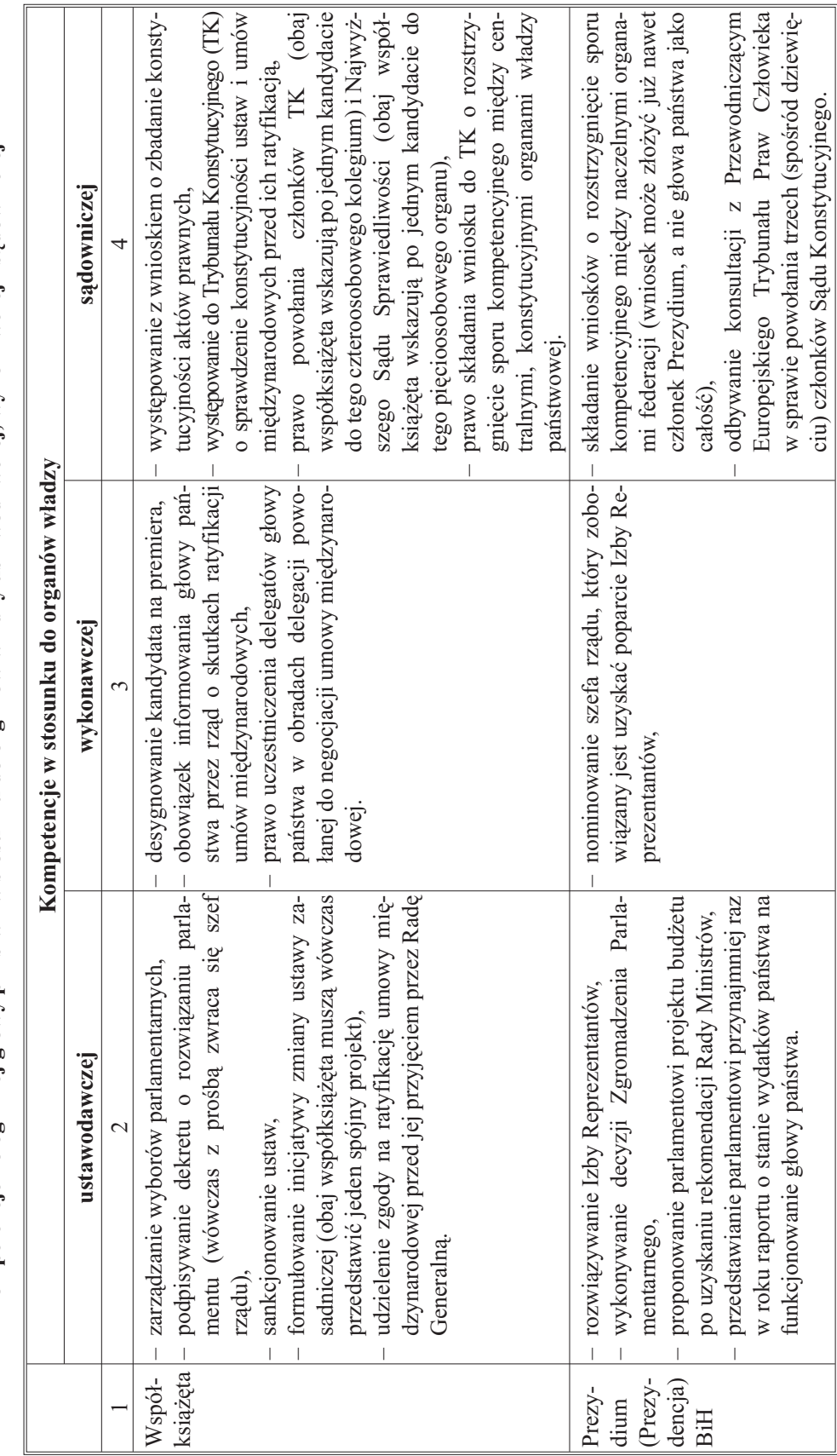




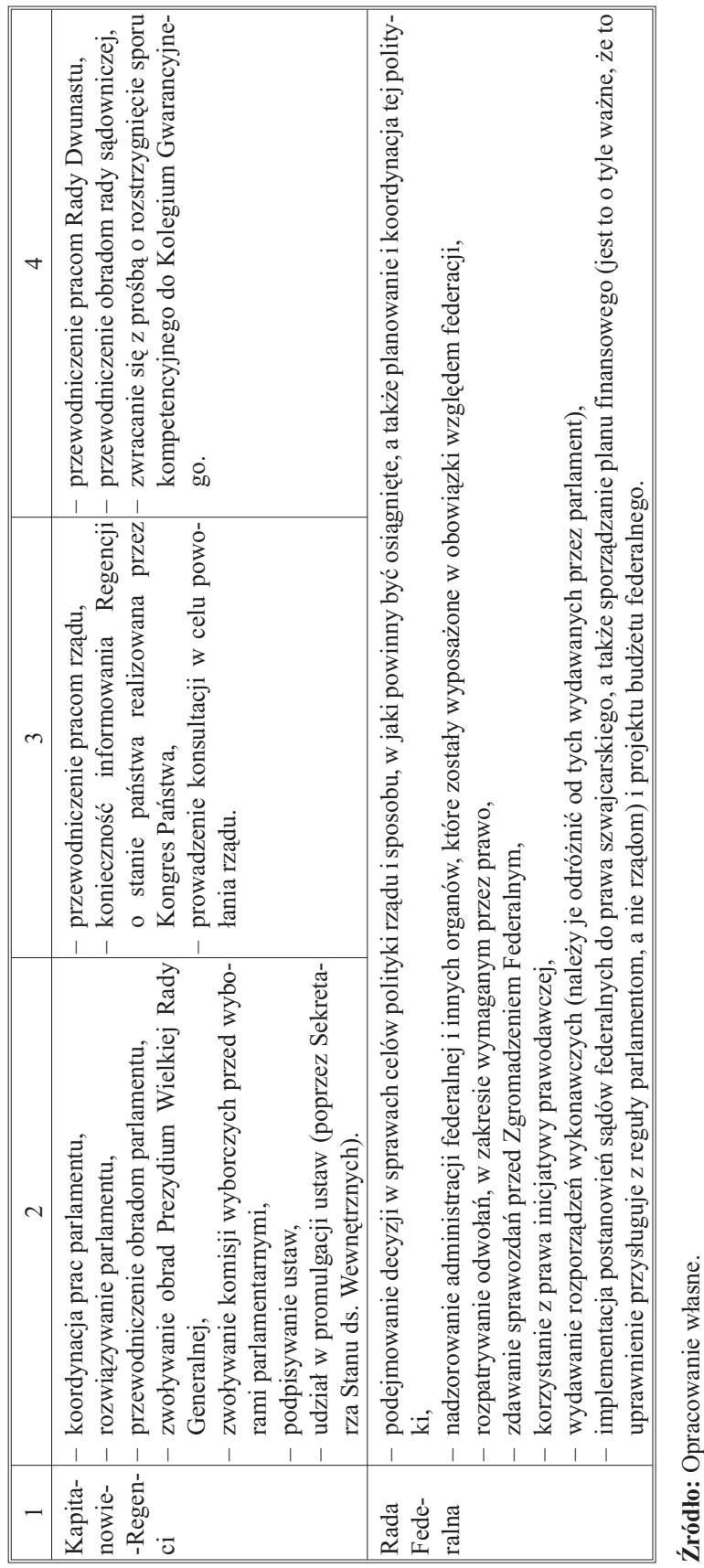


Prezydencja jest uprawniona do wskazywania członków Komitetu Stałego ds. Wojskowych. Członkowie kolegialnej głowy państwa są z urzędu członkami Stałego Komitetu, odpowiedzialnego za nadzorowanie sił zbrojnych. Ponadto, członkowie Prezydencji, mają władzę cywilną nad siłami zbrojnymi. Prezydencja może również podejmować decyzje w celu ułatwienia koordynacji pomiędzy organami i częściami federacji w sprawach, które nie wchodzą w zakres obowiązków federacji przewidzianych w ustawie zasadniczej.

Jednym z klasycznych uprawnień każdej głowy państwa jest przyjmowanie listów uwierzytelniających przedstawicieli dyplomatycznych państw obcych. Ponadto, do klasycznych kompetencji głowy państwa należy zaliczyć przyznawanie orderów. Z obu tych uprawnień korzystają Kapitanowie-Regenci jako organ kolegialny ${ }^{51}$. Poza klasycznymi uprawnieniami Regencji, do uprawnień sanmaryńskiej głowy państwa należy zaliczyć: przyjmowanie petycji w ramach tzw. instancji Arengo, określanie terminu wyborów władz samorządu lokalnego, przewodniczenie konferencji kapitanów zamków oraz przyjmowanie wniosków o wdrożenie ludowej inicjatywy ustawodawczej i o przeprowadzenie referendum (w tym określanie terminu, w którym owo głosowanie ma się odbyć). San Marino jest reprezentowane na arenie międzynarodowej przez głowę państwa, jednak to Kongres Państwa (m.in. poprzez wstępne przyjmowanie traktatów) realizuje i koordynuje główne kierunki polityki zagranicznej Republiki.

W zakresie kompetencji dotyczących reprezentowania Andory na zewnątrz, a także klasycznych uprawnień głowy państwa, współksiążętom przysługuje prawo: wyrażenia zgody na wywiązanie się Księstwa ze zobowiązań wynikających z umów międzynarodowych, zarządzanie referendum (wówczas z prośbą zwraca się do głowy państwa premier) ${ }^{52}$, akredytowanie przedstawicieli obcych państw, a także udzielanie aktu łaski (wyłącznie na podstawie decyzji obu współksiążąt).

Prezydencja Bośni i Hercegowiny posiada bardo szerokie kompetencje. Do grupy uprawnień związanych z reprezentowaniem federacji na zewnątrz i relacji tego organu z innymi organami federacji należy zaliczyć

51 Uroczystość złożenia listów uwierzytelniających miała miejsce w odniesieniu do polskiego ambasadora pod koniec 2010 roku. Wtedy to, Wojciech Ponikiewski złożył listy uwierzytelniające na ręce Kapitanów-Regentów Giovanniego Francesco Ugoliniego i Andrei Zafferaniego. Nine new ambassadors to San Marino, http://www.italica.sm/shownews.php?newsid=0000000682, dostęp 15.12.2010 r.

52 Konstytucja Księstwa Andory..., op. cit., art. 76. 
takie kompetencje jak: wyznaczanie (wraz z parlamentem) symbolów państwa $^{53}$, prowadzenie polityki zagranicznej federacji, powoływanie ambasadorów i innych reprezentantów państwa, a także negocjowanie i wypowiadanie traktatów (za aprobatą Zgromadzenia Parlamentarnego).

Bośniacko-hercegowińska głowa państwa posiada jeszcze uprawnienia specjalne, które przysługują jej jako organowi reprezentującemu federację. Pierwszym jest prowadzenie działań koordynujących z organizacjami międzynarodowymi i pozarządowymi, a drugim jest reprezentowanie federacji w międzynarodowych organizacjach i instytucjach, a także występowanie w sprawach członkostwa państwa w tych organizacjach, których Republika nie jest członkiem.

Zakres władzy głowy państwa wyznaczany jest m.in. przez jej prerogatywy. Ustawa zasadnicza Andory wylicza przypadki, w których współpodpis nie jest wymagany. Są nimi: mianowanie członków Najwyższej Rady Sądownictwa i Trybunału Konstytucyjnego, korzystanie z prawa łaski, organizowanie służb niezbędnych dla właściwego wykonywania swoich funkcji, występowanie do Trybunału Konstytucyjnego z wnioskiem o rozstrzygnięcie sporu kompetencyjnego z innym organem centralnym oraz występowanie do Trybunału z wnioskiem o zbadanie konstytucyjności ustawy lub umowy międzynarodowej ${ }^{54}$.

\section{Szwajcarska głowa państwa - Rada Federalna czy Prezydent Federacji?}

W kwestii określenia szwajcarskiej głowy państwa w literaturze nie ma konsensusu. Część doktryny opowiada się za przyznaniem tego statusu Radzie Federalnej, inni wskazują na szczególną rolę Prezydenta Federacji ${ }^{55}$, któremu to powinno się przyznać ów status. Wreszcie trzecią grupę stanowią autorzy wskazujący na swoistość szwajcarskiego ustroju poli-

53 Konstytucja Bośni i Hercegowiny..., op. cit., art. 1 ust. 6.

54 Konstytucja Księstwa Andory..., op. cit., art. 46.

55 Część autorów stosuje dla przewodniczącego Rady Federalnej termin Prezydent Konfederacji, przyjmując wydawałoby się założenie, że ów przewodniczący jest nie tylko szefem organu, ale i prezydentem - głową państwa. Należy przy tym zaznaczyć, że oficjalną nazwą państwa szwajcarskiego jest Konfederacja Szwajcarska, choć państwo to, od 1848 roku, jest federacją. Szefem Rady Federalnej jest jednak nie Prezydent Konfederacji, a Prezydent Federacji (Bubdespräsident). Por. A. Pułł, Ustroje państw współczesnych, Warszawa 2007, s. 240-241. 
tycznego, w którym Prezydent Federacji nie jest ani premierem, ani prezydentem w klasycznym rozumieniu tych pojęc ${ }^{56}$.

W kwestii reprezentacji Konfederacji Szwajcarskiej, ustawa zasadnicza stanowi, że odpowiedzialna jest za to Rada Federalna ${ }^{57}$. A. Pułło wskazuje, że funkcje reprezentacyjne, takie jak przyjmowanie wysokich przedstawicieli państw obcych przysługują Radzie Federalnej in corpo$r e^{58}$. Zgodnie z delegacją konstytucyjną, to Rada Federalna jest odpowiedzialna za podpisanie traktatu, który następnie musi zostać przekazany do parlamentu celem akceptacji i zakończenia procesu ratyfikacji ${ }^{59}$.

Szerokie uprawnienia przysługują Radzie Federalnej w sprawie stosunków między władzami federalnymi a kantonalnymi: rząd jest zobowiązany do utrzymywania dobrych stosunków z kantonami oraz zatwierdzania aktów stanowionych przez kantony, gdy jest to wymagane przez prawo kantonalne. Ponadto, głowa państwa może zakwestionować ratyfikację traktatów między kantonami a innymi podmiotami, a także jest odpowiedzialna za sprawowanie kontroli nad stanowieniem prawa przez kantony i ich zgodnością z ustawodawstwem federalnym.

Ostatnią grupą uprawnień szwajcarskiej głowy państwa są te dotyczące zapewnienia bezpieczeństwa wewnętrznego i zewnętrznego. Zgodnie z art. 185 ustawy zasadniczej, w przypadku zagrożenia naruszenia integralności terytorialnej i neutralności państwa, Rada Federalna władna jest wydać specjalne zarządzenia (które muszą być czasowo ograniczone). Może też, jeżeli będzie to konieczne, ogłosić mobilizację sił zbrojnych. Konstytucja stanowi, że wówczas niezwłocznie powinno zostać zwołane posiedzenie parlamentu ${ }^{60}$.

Szef szwajcarskiego rządu (Prezydent Federacji) poza tym, że jest primus inter pares, ma też jedno poważniejsze uprawnienie niż tylko przewodniczenie obradom Rady Federalnej. Jest nim możliwość wydawania zarządzeń w sprawach pilnych, które trafiają pod obrady Rady Federalnej, która je zatwierdza.

56 A. Antoszewski, R. Herbut, Systemy polityczne współczesnej Europy, Warszawa 2007, s. 187; Z. Czeszejko-Sochacki, System konstytucyjny Szwajcarii, Warszawa 2002, s. 59.

${ }^{57}$ Konstytucja Federalna Konfederacji..., op. cit., art. 184 ust. 1.

58 A. Pułło, Ustroje państw..., op. cit., s. 241.

59 Konstytucja Federalna Konfederacji..., op. cit., art. 184 ust. 2.

60 Ibidem, art. 185. 
Wybrane kompetencje zwyczajowo przysługujące głowie państwa, zostały przedstawione w tabeli 3 . Wydaje się, że najważniejszym uprawnieniem głowy państwa jest reprezentowanie w stosunkach międzynarodowych. Rolę tę spełnia Rada Federalna. Nie należy jednak zapominać o innych uprawnieniach głowy państwa. Specyfika ustroju Szwajcarii przejawia się m.in. w tym, że wiele z klasycznych uprawnień głowy państwa przekazane są parlamentowi (prawo łaski), rządowi (ratyfikacja traktatów), przewodniczącym izb parlamentarnych (podpisanie ustaw), władzom kantonów (sprawy obywatelstwa) czy też w ogóle ich nie ma (zwierzchnictwo nad siłami zbrojnymi przysługuje Szefowi Armii). Należy przy tym zauważyć, że to specyfika ustroju szwajcarskiego opartego na supremacji władzy parlamentu i federacyjnej budowie państwa determinuje przekazanie wielu klasycznych uprawnień głowy państwa na inne organy $^{61}$.

Problemem, który należy rozstrzygnąć, jest status szwajcarskiego Prezydenta Federacji, który przez część doktryny wskazywany jest jako jednoosobowa głowa państwa, a przez innych jako szef kolegialnej głowy państwa. Nie podlega wątpliwości, że argumentem przemawiającym za przyznaniem statusu głowy państwa Prezydentowi Federacji jest już sama nazwa (wskazuje ona bowiem na przewodniczenie nie tyle Radzie Federalnej, ale właśnie Konfederacji Szwajcarskiej). Kolejnym argumentem może być posiadanie przez szefa rządu prawa do wydawania zarządzeń pilnych, co wzmacnia pozycję ustrojową Prezydenta Federacji względem pozostałych członków Rady Federalnej.

Argumentem zwolenników tezy o istnieniu kolegialnej głowy państwa w Szwajcarii jest niewątpliwie zapis konstytucyjny o reprezentowaniu państwa przez Radę Federalną, a nie jej przewodniczącego (art. 184 ust. 1). Trzeba też zauważyć, że art. 28 ustawy o organizacji rządu i administracji stanowi, że Prezydent (lub w jego zastępstwie Wiceprezydent) reprezentuje Radę Federalną w stosunkach wewnętrznych i zewnętrznych $^{62}$, co wyraźnie wskazuje na prawo reprezentowania wyłącznie Rady Federalnej jako organu państwa (a nie federacji jako takiej). Ponadto, jak wskazano w tabelach 2 i 3, część uprawnień, stanowiących - wydawałoby się - kanon uprawnień głowy państwa w Bośni i Hercegowinie, Andorze i San Marino jest przeniesiona na inne organy państwa. Wobec tego nie

61 P. Sarnecki, Ustroje konstytucyjne państw..., op. cit., s. 312.

62 Ustawa o organizacji rządu i administracji z 21 marca 1997 roku, art. 28. 
możemy stwierdzić, że skoro głowa państwa w III RP i PRL posiada/posiadała wskazane w tabeli uprawnienia i bezspornie posiada status głowy państwa, to organ nieposiadający choćby części owych uprawnień za głowę państwa nie może zostać uznany.

Podsumowując, za P. Sarneckim, szef rządu spełnia raczej czynności czysto protokolarne. Co wydaje się potwierdzać przytoczoną we wprowadzeniu tezę o przysługującym Radzie Federalnej statusie szwajcarskiej głowy państwa ${ }^{63}$.

Tabela 2

Wybrane uprawnienia głowy państwa w Andorze i Bośni i Hercegowinie w porównaniu z uprawnieniami głowy państwa w PRL i III RP

\begin{tabular}{|c|c|c|c|c|}
\hline \multirow{2}{*}{$\begin{array}{c}\text { Wybrane upraw- } \\
\text { nienia glowy państ- } \\
\text { wa }\end{array}$} & \multicolumn{2}{|c|}{$\begin{array}{l}\text { Państwa, które posiadają w swym } \\
\text { ustroju kolegialną głowę państwa }\end{array}$} & \multirow{2}{*}{ PRL } & \multirow{2}{*}{ III RP } \\
\hline & Andora & Bośnia i Hercegowina & & \\
\hline $\begin{array}{l}\text { Reprezentowanie pa- } \\
\text { ństwa w stosunkach } \\
\text { zewnętrznych }\end{array}$ & współksiążęta & Prezydencja BiH & Rada Państwa & prezydent \\
\hline $\begin{array}{l}\text { Przyjmowanie listów } \\
\text { uwierzytelniających }\end{array}$ & \begin{tabular}{|l|} 
współksiążęta \\
(de facto: ich re- \\
prezentanci)
\end{tabular} & $\begin{array}{l}\text { Przewodniczący Prezy- } \\
\text { dencji BiH (ale dopiero } \\
\text { po uchwaleniu agrém- } \\
\text { ent przez Prezydium) }\end{array}$ & Rada Państwa & prezydent \\
\hline Prawo łaski & współksiążęta & Prezydencja $\mathrm{BiH}$ & Rada Państwa & prezydent \\
\hline $\begin{array}{l}\text { Nadawanie obywa- } \\
\text { telstwa }\end{array}$ & $\begin{array}{l}\text { administracja } \\
\text { rządowa }\end{array}$ & $\begin{array}{l}\text { minister spraw wew- } \\
\text { nętrznych }\end{array}$ & Rada Państwa & prezydent \\
\hline $\begin{array}{l}\text { Prawo weta ustawo- } \\
\text { dawczego }\end{array}$ & brak & brak & brak & prezydent \\
\hline \begin{tabular}{|l} 
Formalne \\
nictwo nierzch- \\
zbrojnymi
\end{tabular} & \begin{tabular}{|l|} 
brak sił zbrojnych \\
(za obronę odpo- \\
wiadają sąsiedzi)
\end{tabular} & $\begin{array}{l}\text { członkowie Prezyden- } \\
\text { cji BiH }\end{array}$ & $\begin{array}{l}\text { brak określe- } \\
\text { nia w konsty- } \\
\text { tucji }\end{array}$ & prezydent \\
\hline $\begin{array}{l}\text { Zarządzanie wyborów } \\
\text { parlamentarnych }\end{array}$ & współksiążęta & $\begin{array}{l}\text { Centralna Komisja Wy- } \\
\text { borcza }\end{array}$ & Rada Państwa & prezydent \\
\hline
\end{tabular}

Źródlo: Opracowanie własne.

${ }^{63}$ P. Sarnecki, Ustroje konstytucyjne państw..., op. cit., s. 312. 
Wybrane uprawnienia głowy państwa w San Marino i Szwajcarii w porównaniu $z$ uprawnieniami głowy państwa w PRL i III RP

\begin{tabular}{|c|c|c|c|c|}
\hline \multirow{2}{*}{\begin{tabular}{|c|} 
Wybrane \\
uprawnienia glowy \\
państwa
\end{tabular}} & \multicolumn{2}{|c|}{$\begin{array}{l}\text { Państwa, które posiadają w swym } \\
\text { ustroju kolegialną glowę państwa }\end{array}$} & \multirow[t]{2}{*}{ PRL } & \multirow[t]{2}{*}{ III RP } \\
\hline & San Marino & Szwajcaria & & \\
\hline $\begin{array}{l}\text { Reprezentowanie pa- } \\
\text { ństwa w stosunkach } \\
\text { zewnętrznych }\end{array}$ & $\begin{array}{l}\text { Kapitanowie- } \\
\text {-Regenci }\end{array}$ & $\begin{array}{l}\text { Rada } \\
\text { Federalna }\end{array}$ & Rada Państwa & prezydent \\
\hline $\begin{array}{l}\text { Przyjmowanie listów } \\
\text { uwierzytelniających }\end{array}$ & $\begin{array}{l}\text { Kapitanowie- } \\
\text {-Regenci }\end{array}$ & $\begin{array}{l}\text { Prezydent } \\
\text { Federacji }\end{array}$ & Rada Państwa & prezydent \\
\hline Prawo łaski & $\begin{array}{l}\text { Kapitanowie- } \\
\text {-Regenci }\end{array}$ & $\begin{array}{l}\text { Zgromadzenie } \\
\text { Parlamentarne }\end{array}$ & Rada Państwa & prezydent \\
\hline $\begin{array}{l}\text { Nadawanie obywa- } \\
\text { telstwa }\end{array}$ & $\begin{array}{l}\text { Wielka Rada } \\
\text { Generalna }\end{array}$ & $\begin{array}{l}\text { władze } \\
\text { kantonalne }\end{array}$ & Rada Państwa & prezydent \\
\hline $\begin{array}{l}\text { Prawo weta ustawo- } \\
\text { dawczego }\end{array}$ & brak & $\begin{array}{l}\text { brak (wyłącznie } \\
\text { w formie weta } \\
\text { ludowego) }\end{array}$ & brak & prezydent \\
\hline \begin{tabular}{l}
\multicolumn{3}{|l|}{ Formalne } \\
nictwo naierzch- \\
zbrojnymi
\end{tabular} & $\begin{array}{l}\text { Kapitanowie- } \\
\text {-Regenci }\end{array}$ & $\begin{array}{l}\text { Szef Armii podle- } \\
\text { gający Radzie Fe- } \\
\text { deralnej }\end{array}$ & $\begin{array}{l}\text { brak określenia } \\
\text { w konstytucji }\end{array}$ & prezydent \\
\hline $\begin{array}{l}\text { Zarządzanie wyborów } \\
\text { parlamentarnych }\end{array}$ & $\begin{array}{l}\text { Kapitanowie- } \\
\text {-Regenci }\end{array}$ & brak & Rada Państwa & prezydent \\
\hline
\end{tabular}

Źródło: Opracowanie własne.

\section{Podsumowanie}

Podsumowując, należy wskazać, że obecnie mamy do czynienia z dwoma typami kolegialnej głowy państwa: pierwszym jest głowa państwa, której człony konstytutywne są równe względem siebie, a decyzja głowy państwa nie może zostać podjęta bez zgody obu członów. Taki typ reprezentuje obecnie naczelny organ Andory i San Marino. Drugim typem jest organ kolegialny, w którym członkowie są równi względem siebie, a jeden z członów jest przewodniczącym tego organu (jednak jako primus inter pares). Ten typ reprezentuje obecnie szwajcarska i bośniacko-hercegowińska głowa państwa.

Ponadto, należy wskazać, że wobec przytoczonych argumentów, za głowę państwa szwajcarskiego należy uznać Radę Federalną. Pomimo posiadania przez Prezydenta Federacji kompetencji do wydawania zarządzeń pilnych, organ ten wydaje się być jedynie przewodniczącym kolegialnej głowy państwa. 


\section{Summary}

A vast majority of democratic constitutions provide for a unipersonal head of state in modern political systems. There are only four democratic states with a collegial head of state in their political system. In the opinion of the article's author, this form of the principal state organ is determined by historical factors and/or the federal character of the state. The author also points to the fact that this form of state leadership is present in the political systems of autocratic states. 